\title{
Jujubinus silbogomerus n. sp. (Gastropoda Trochidae) from the Canary Islands, Atlantic Ocean
}

\author{
Carlo Smriglio ${ }^{*}$, Paolo Mariottini' \& Frank Swinnen ${ }^{\dagger 2}$ \\ ${ }^{1}$ Dipartimento di Scienze, Università di Roma Tre, Viale Marconi, 446, 00146 Roma, Italy; e-mail: csmriglio@alice.it; \\ paolo.mariottini@uniroma3.it \\ ${ }^{\dagger}$ Royal Belgian Institute of Natural Sciences, D.O. Taxonomy \& Phylogeny Vautier Street 29, 1000 Brussels, Belgium; \\ e-mail: f.swinnen.lommel@telenet.be \\ ${ }^{2}$ Estação de Biologia Marinha and Museu Municipal do Funchal, Madeira. Cais do Carvão Promenade da Orla Marítima do \\ Funchal \\ "Corresponding author, email: csmriglio@alice.it
}

ABSTRACT

KEY WORDS
Based on shell characters, a new species of the gastropod family Trochidae, Jujubinus silbogomerus n. sp., is described from the Atlantic Ocean. The new taxon is known from the type locality only, the Canary Islands. It was compared with the most closely related species of this geographical area as well as with the Atlantic and Mediterranean Jujubinus Monterosato, 1884 showing marked sculpture. The peculiar morphology of the teleoconch microsculpture and sculpture of this new taxon allows an easy identification.

Recent; Trochidae; Jujubinus silbogomerus; new species; Atlantic Ocean.

Received 19.10.2019; accepted 28.10.2019; published online 11.12.2019

\section{INTRODUCTION}

The genus Jujubinus Monterosato, 1884, currently under review (manuscript in preparation), actually is represented in the eastern European Atlantic Ocean and the Mediterranean Sea by 26 nominal species according to MOLLUSCABASE (http://www.molluscabase.org; last access October 2019). The shell of the genus Jujubinus typically displays a slender trochiform shape, with a marked sculpture consisting of 4 to 8 spirals often threads beaded and variable in size, with an evident basal cord, and with tiny prosocline lamellae within thread interspaces (Monterosato, 1884). The largest percentage of Jujubinus species are living in the intertidal zone down to about 80 meters, few can occur on the bathyal bottoms and are constantly associated with photophilic algal vegetation and/or marine phanerogames (Mariottini et al., 2013; Rolàn \& Swinnen, 2013). In the Canary Islands, the genus Jujubinus has been studied in the past with the description of several species (Rolàn \& Swinnen, 2009; Rolàn \& Swinnen, 2013), which are mainly endemic of this geographical area. Living specimens of a new species, here described as J. silbogomerus $\mathrm{n}$. sp., were sampled by SCUBA diving from the rocky bottoms of the island of Gomera, Canary Islands, off the coast of San Sebastian.

ACRONYMS. The materials used for this study are deposited in the following private and Museum collections: CS-PM: Carlo Smriglio-Paolo Mariottini, Rome, Italy; FS: Frank Swinnen, Lommel, Belgium; MCZR: Museo Civico di Zoologia di Roma, Rome, Italy; MNHN: Muséum National d'Histoire Naturelle, Paris, France; RBINS: Institus Royal des Sciences Naturelles de Belgique, Brussels, Bel- 
gium. Other acronyms used in the text: $\mathrm{H}$ : Height; LIME: Interdepartmental Laboratory of Electron Microscopy; SEM: Scanning Electron Microscopy; shell (sh); W: Width.

\section{MATERIALS AND METHODS}

Twenty-one specimens (including juveniles, subadults and adults stages) of J. silbogomerus $\mathrm{n}$. sp. were collected while SCUBA diving at a depth of $18 \mathrm{~m}$ in La Gomera Island (Playa la Cueva), Canary Islands, Spain. Sampling was consisting mainly of empty shells (shs), few individuals were collected alive. Scanning Electron Microscopy (SEM) photographs were taken at the Interdepartmental Laboratory of Electron Microscopy (LIME, Università "Roma Tre", Rome, Italy), using a Philips XL30. Current systematic here adopted is based on World Register of Marine Species (WoRMS, http://www. marinespecies.org/; last access October 2019). The Jujubinus species stored in the Monterosato's collection at the Museo Civico di Zoologia di Roma (MCZR) have been investigated for comparison with J. silbogomerus $\mathrm{n}$. sp. In particular, shells of Jujubinus tumidulus: 1 sh labeled, "Trochus tumidulus Aradas Pliocen. Pleistocenico"; 2 shs labeled, "Jujubinus tumidulus (Aradas) Palermo", ex Bellini collection, Sicily, Italy; 123 shs labeled, "P", Palermo, Sicily, Italy, MCZR-M-11713, MTS; 13 shs labeled, "S. vito", San Vito Lo Capo, Trapani, Sicily, MCZR-ME12/4, MTS; Linosa Island, Punta Calcarello, 36 $\mathrm{m}$, Sicily, Italy, 11 shs, CS-PM; Linosa Island, 3 Ceppi, 28 m, Sicily, Italy, 50 shs, CS-PM; Marettimo Island, $45 \mathrm{~m}$, Sicily, Italy, 5 shs, CS-PM; Scilla, Strait of Messina, 42 m, Italy, 40 shs, CSPM.

Shells of Jujubinus montagui: Shetland Islands, United Kingdom, 11 shs labeled, "Shetland M'Andr." (ex Mc Andrew collection), MCZR-ME12/14, MTS; Aberdeen, United Kingdom, 5 shs labeled, "Trochus montacuti nt Aberdeen" (synonym), MCZR-M-E12, MTS; St. Malò, France, 9 shs, MCZR-M-11756, MTS; 1 sh labeled, "Jujubinus turgidulus Brocchi”, MCZR-M-11713, MTS; Bastia, France, 5 shs, labeled "Trochus montacuti" ex Caziot collection, MCZR-M-11715, MTS; Capri, Italy, 2 shs, MCZR-M-11716, MTS; Sine Loco, "Coll Weink.", 1 sh, MCZR-M-11713, MTS;
Anzio, 50 m, Latium, Italy, 120 shs, CS-PM; Fiumicino, fishing boats, $160 \mathrm{~m}$, Latium, Italy, 4 shs, CS-PM; Caprera, Punta Crucitta, 78 m, Sardinia, Italy, 1 sh, CS-PM; San Vito, Trapani, Sicily, Italy, 7 shs, MCZR-M-11761, MTS; Sfax, 60 miles to the east, $100 \mathrm{~m}$, Tunisia, 7 shs, CS-PM.

\section{RESULTS}

\section{Systematics}

Classis GASTROPODA Cuvier, 1795

Subclassis VETIGASTROPODA Salvini-Plawen, 1980

Ordo TROCHIDA Rafinesque, 1815

SuperfamiliaTROCHOIDEA Rafinesque, 1815

Familia TROCHIDAE Rafinesque, 1815

Subfamilia TROCHINAE Rafinesque, 1815

Genus Jujubinus Monterosato, 1884

Type species: Trochus matoni Payraudeau, 1826

(by subsequent designation)

Jujubinus silbogomerus n. sp. (Figs. 1-17, 24-26)

Diagnosis. Small and little turriculate shell, with sculpture of incised spiral lines and strong prosocline lamellae between and over spiral cords, micropustules within interspaces.

EXAMINED MATERIAL. The holotype, MT.3820 / I.G. 34082, RBINS, and the paratype "A", MNHNIM-2014-7994, the paratype "B, M-S" CS-PM coll.; the paratype "C-L", FS coll., all from type locality: La Gomera Island (off Playa de la Cueva, San Sebastian, $18 \mathrm{~m}$ deep, $28^{\circ} 06^{\prime} \mathrm{N} 17^{\circ} 06^{\prime} \mathrm{W}$ ), Canary Islands, Spain, Atlantic Ocean; and three very young shells without soft parts, FS coll.

DESCRIPTION OF HOLOTYPE. Shell conical, of relatively small size for the genus, height (H) $2.8 \mathrm{~mm}$, width (W) $2.8 \mathrm{~mm}$, slightly shiny. Protoconch smooth of about 1.5 whorls. Teleoconch of 4.5 slightly convex whorls. Sculpture of 6 abapical spiral cords, regularly spaced and of about the same strength, with a strongly carved basal cord. Other basal cords narrow and well engraved, composed of two close threads, with very evident and strong lamellae in the interspace. First two whorls of the teleoconch showing a step on the shoulder and the spiral peripheral cord to the suture very highlighted 


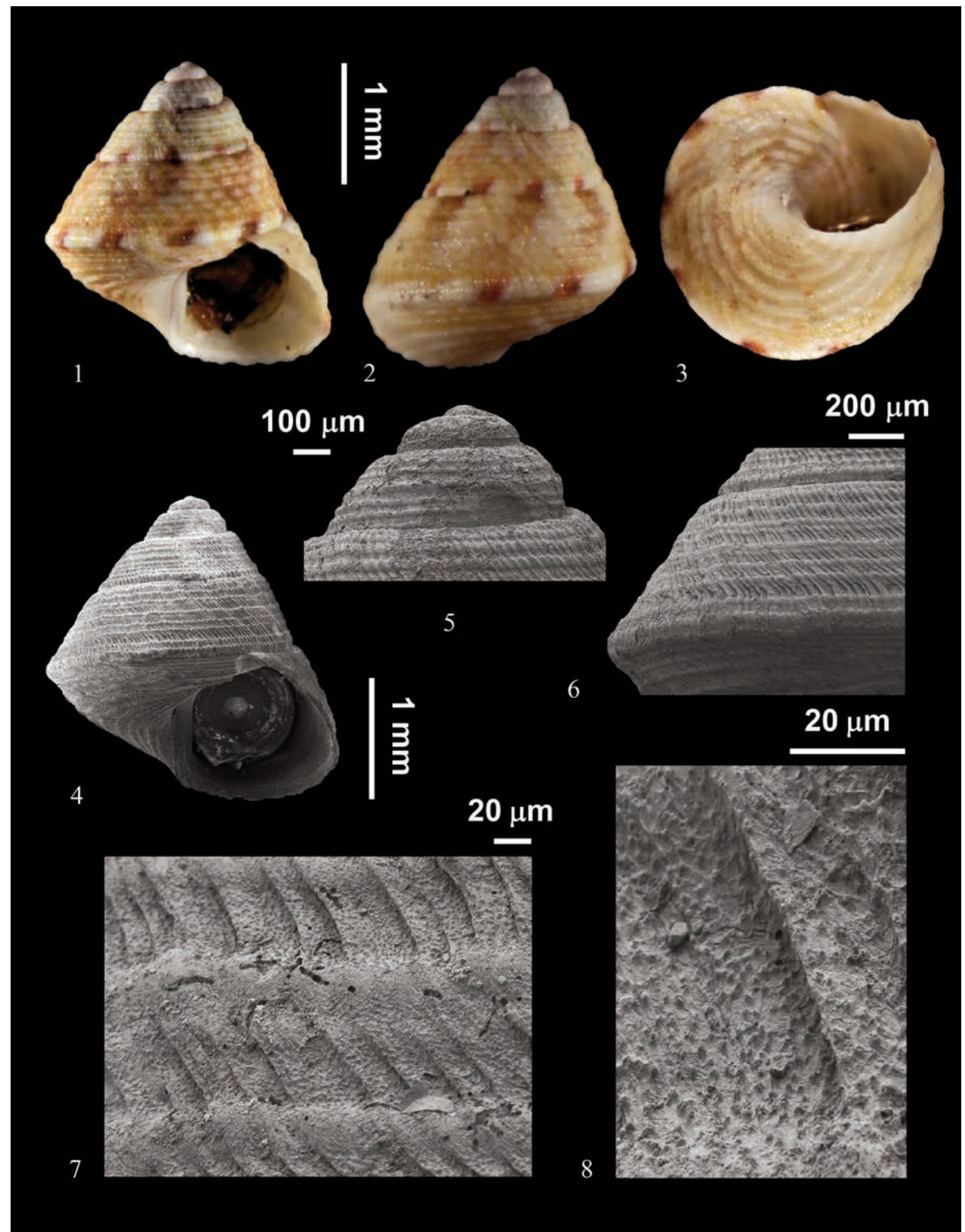

Figures 1-8. Jujubinus silbogomerus n. sp., holotype, La Gomera Island, Canary Islands, Spain, Atlantic Ocean. Figs. 13: shell, 2.8 (H) X 2.8 mm (W), frontal, dorsal and basal view, MT.3820 / I.G. 34082, RBINS. Fig. 4: idem, SEM uncoated, frontal view. Fig. 5: idem, SEM detail of the protoconch and of the first teleoconch whorls. Fig. 6: idem, SEM, detail of the shell whorl. Fig. 7: idem, SEM detail of microsculpture. Fig. 8: idem, SEM, detail of the surface covered by micropustule. 


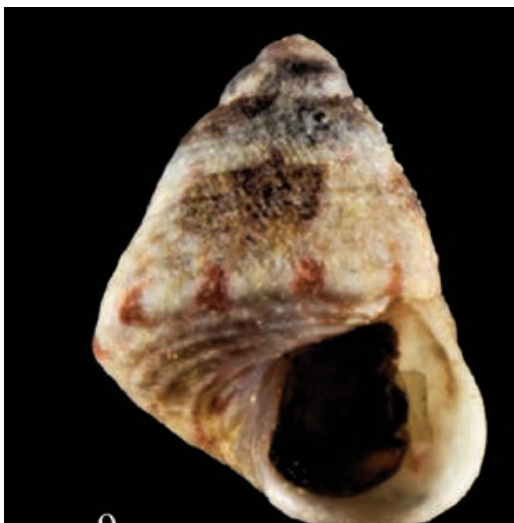

9

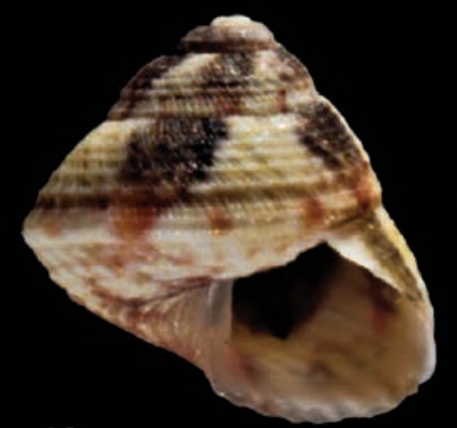

12

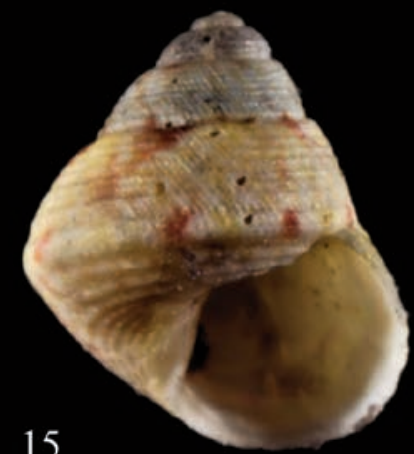

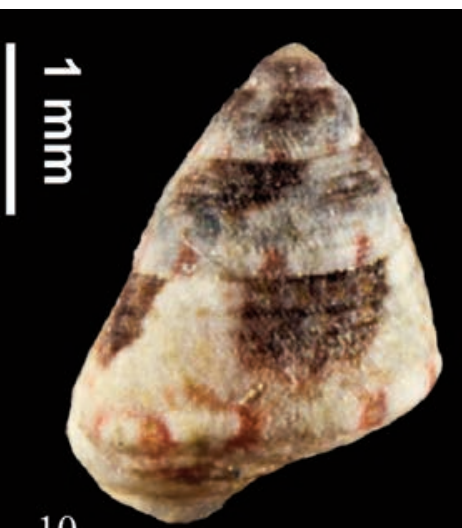

10

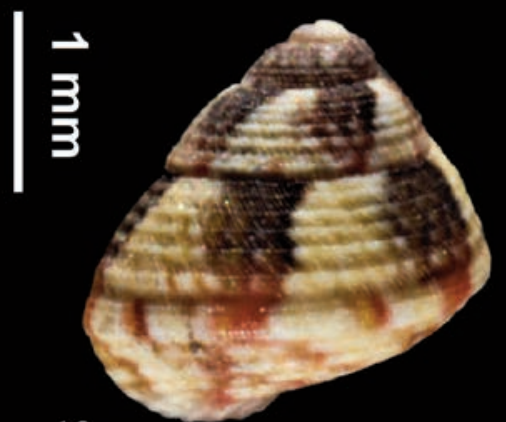

13

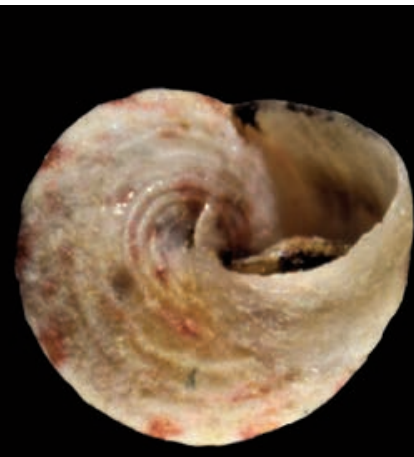

11

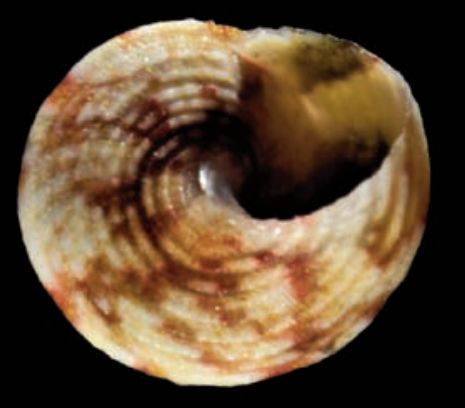

14

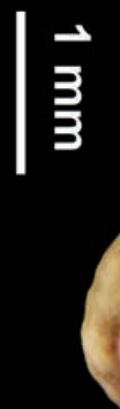

16
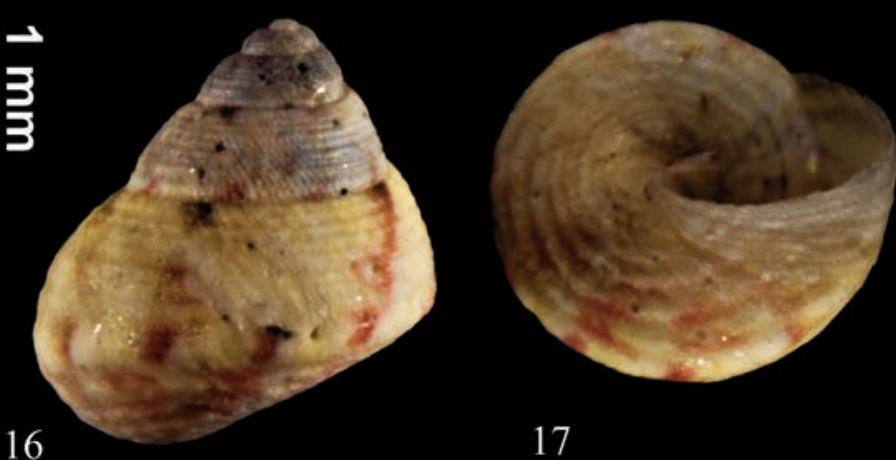

17

Figures 9-11. Jujubinus silbogomerus n. sp., Paratype “A”, 3.0 (H) X 2.7 mm (W). MNHN-IM-2014-7994, La Gomera Island, Canary Islands, Spain, Atlantic Ocean; optical frontal, dorsal and basal views. Figures 12-14. Jujubinus silbogomerus n. sp., Paratype "B", 2.4 (H) X 2.5 mm (W), CS-PM, La Gomera Island, Canary Islands, Spain, Atlantic Ocean, optical of frontal, dorsal and basal views. Figures 15-17. Jujubinus silbogomerus n. sp., Paratype "C", $2.8(\mathrm{H})$ X 2.5 mm (W), FS, La Gomera Island, Canary Islands, Spain, Atlantic Ocean, optical of frontal, dorsal and basal views.

from the ripple produced from the dense axial lamellae; last teleoconch whorls with a less pronounced basal cord. Suture incised. Surface of the teleoconch completely covered by very visible prosocline lamellae, arranged almost regularly, which end above the spiral cords, giving to the shell a crenulated appearance. Base convex, umbilicus closed and covered with a white callus. Aperture quadrangular, with the columellar callus positioned in the middle portion and internally whitish nacreous. Colour of protoconch whitish, teleoconch yellowish-creamy, with brownish quadrangular spots and basal cord coloured by short reddish - brownish spots. Basal disc yellowish interrupted by broad 


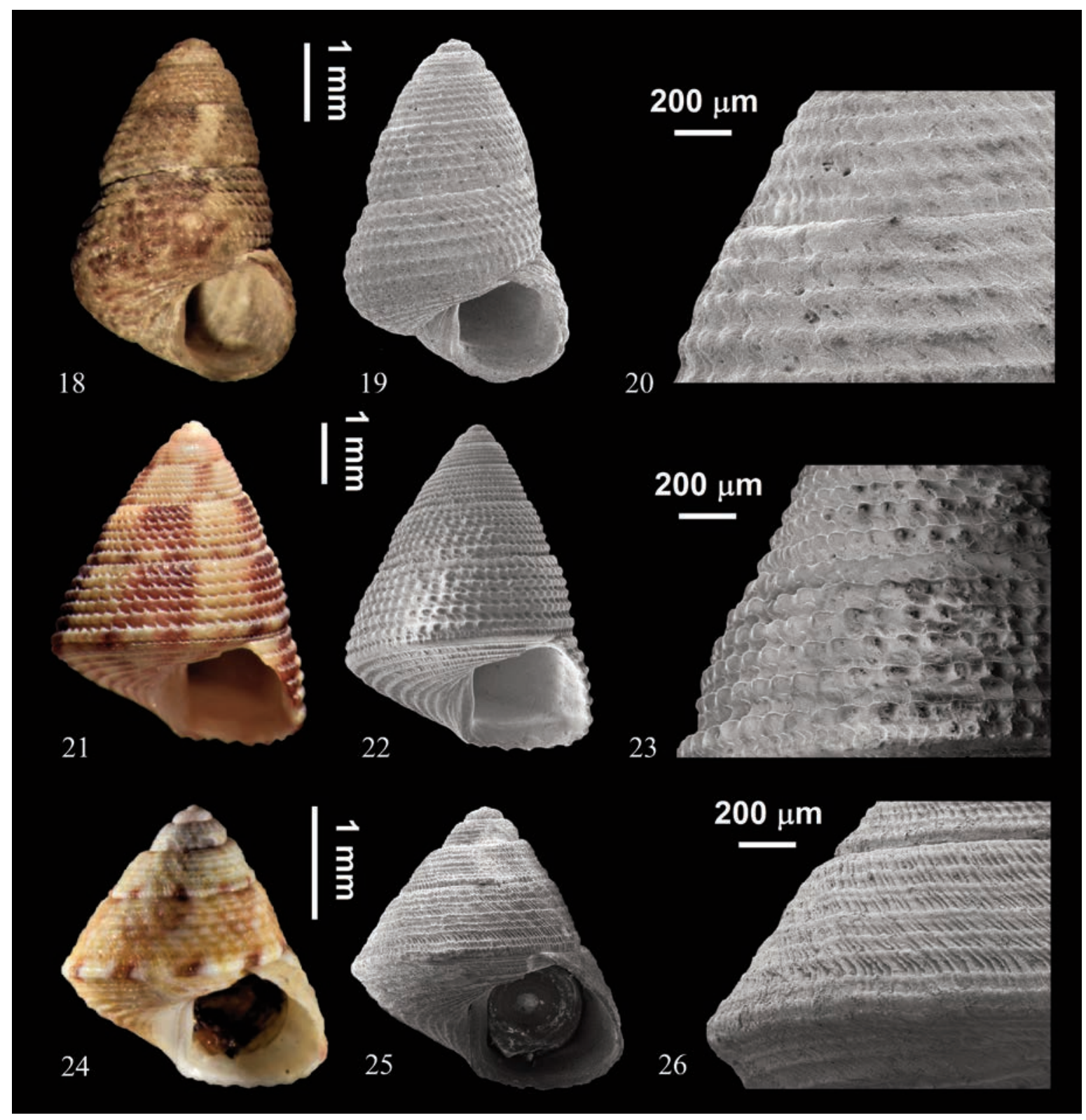

Figures 18-20. Jujubinus tumidulus, Palermo, Italy, 4.8 (H) X 2.5 (W) mm, frontal view, MCZR-M-11713, MTS (Fig. 18); SEM frontal view, uncoated (Fig. 19); SEM detail of the shell (Fig. 20). Figures 21-23. Jujubinus montagui, 4.5 (H) X 3.6 mm (W), frontal view, CS-PM (Fig. 21); SEM frontal view, uncoated (Fig. 22); SEM detail of the shell (Fig. 23). Figures 24-26. Jujubinus silbogomerus $\mathrm{n}$. sp., holotype, La Gomera, Canary Islands, 2.8 (H) X $2.8 \mathrm{~mm}(\mathrm{~W})$, frontal view, MT.3820 / I.G. 34082, RBINS (Fig. 24); SEM frontal view, uncoated (Fig. 25); SEM detail of the shell (Fig. 26).

reddish-brownish lines decorated with 6-7 circular cords. Multispiral operculum.

VARIABILITY. Shell $\mathrm{H}$ ranging from 2.8 to $3.0 \mathrm{~mm}$ and $\mathrm{W}$ from 2.5 to $2.8 \mathrm{~mm}$.

ETYMology. The species is named after the Silbo Gomero (whistle of La Gomera), the ancient whis- tle language which was used in the past by shepherds of La Gomera Island to communicate over great distances, now included in the oral and intangible heritage of humanity protected by UNESCO (United Nations Educational Scientific and Cultural Organization), (https://unesdoc.unesco.org, last access 10. 02. 2019). 
Distribution AND Biology. Currently only known from La Gomera Island, Atlantic Ocean, type locality.

This species seems to prefer habitat with poor vegetation and bottoms with hard substrate from which come the majority of living specimens object of the present work.

\section{DISCUSSION AND CONCLUSIONS}

Jujubinus silbogomerus $\mathrm{n}$. sp. has very peculiar shell morphology, consisting in a strong sculpture enriched by the typical interspaced prosocline lamellae, which are dense and producing a rough looking shell surface. This peculiar sculpture was never described in the species attributed to the genus Jujubinus and it is comparable only with that of J. montagui (Wood, 1828) known for Mediterranean, European Atlantic, Morocco and the Canary Islands (Hernàndez et al., 2011) and Madeira (Segers et al., 2009), and that of J. tumidulus (Aradas, 1846), which seems to be geographically present only in the Mediterranean Sea, mostly localized in the southern Tyrrhenian Sea (Scaperrotta et al., 2009). Jujubinus montagui also shows a strong and exalted sculpture with tuberculate spiral cords and small interspaces containing short, robust and spaced prosocline lamellae, but not as dense as the new taxon. Furthermore, J. montagui has a larger size and different general shape and colour, while $J$. silbogomerus $\mathrm{n}$. sp. is provided of small spiral cords sculpted but inconspicuous with interspaces totally occupied by prosocline lamellae closely spaced with micropustules, absent in $J$. montagui, that cover the entire surface. Jujubinus tumidulus is also provided with an exalted sculpture, but the spiral cords are highly tuberculated with spaced lamellae in the interspaces but without micropustules. This species has a very turreted shape, while J. silbogomerus n. sp. is rather compressed in outline, which shows also a different colour pattern. Currently, in both Atlantic Ocean and Mediterranean Sea only J. silbogomerus $\mathrm{n}$. $\mathrm{sp}$. presents this morphology and unique peculiar teleoconch sculpture, allowing its identification easily and unambiguously.

\section{ACKNOWLEDGEMENTS}

We thank very much Andrea Di Giulio (Dipartimento di Scienze, Università Roma Tre, Rome, Italy) for the SEM photographs carried out at the LIME (Laboratorio Interdipartimentale di Microscopia Elettronica, University Roma Tre, Rome, Italy). We would like to express our gratitude to Massimo Appolloni (Museo Civico di Zoologia, Rome, Italy) for the examination of the Jujubinus material kept in the Monterosato collection.

\section{REFERENCES}

Hernàndez J.M., Rolàn E., Swinnen F., Gòmez R. \& Perez J.M., 2011. Moluscos y Conchas Marinas de Canarias. ConchBooks, Germany, 716 pp., 130 pl.

Mariottini P., Di Giulio A., Appolloni M. \& Smriglio C., 2013. Phenotypic diversity, taxonomic remarks and updated distribution of the Mediterranean Jujubinus baudoni (Monterosato, 1891) (Gastropoda Trochidae). Biodiversity Journal, 4: 343-354.

MOLLUSCABASE http://www.molluscabase.org

Monterosato T., Di Maria, 1884. Nomenclatura generica e specifica di alcune conchiglie mediterranee. Stabilimento Tipografico Virzì, Palermo, 152 pp.

Rolàn E. \& Swinnen F., 2009. Two new species of the genus Jujubinus (Mollusca, Trochidae) from the Canary Islands. Gloria Maris, 48: 90-98.

Rolàn E. \& Swinnen F., 2013. A new species of the genus Jujubinus from the Canary Islands (Gastropoda, Trochoidea, Trochidae). Gloria Maris, 52: 172-177.

Scaperrotta M., Bartolini S. \& Bogi C., 2009. Accrescimenti. Stadi di accrescimento dei molluschi marini del Mediterraneo. Vol. 1. L'Informatore Piceno, Ancona, $167 \mathrm{pp}$.

Segers W., Swinnen F. \& De Prins R., 2009. Marine molluscs of Madeira. Snoeck Publishers, Belgium, 612 pp., $90 \mathrm{pl}$.

UNESDOC Digital Library, https://unesdoc.unesco.org 